\title{
Os compromissos do médico: reflexões sobre a oração de Maimônides
}

\section{Commitments of medicine: reflections on the prayer of Maimonides}

ISAC JORGE FILHO - ECBC-SP ${ }^{1}$

\author{
R E S U M O
}

\begin{abstract}
Ciência/Arte milenar, a Medicina envolve, pela sua natureza, compromissos firmes com princípios básicos da Bioética e que se resumem na busca da saúde e bem-estar das pessoas e comunidades em seu mais amplo sentido. Tais compromissos podem ser mais formais, como os de obediência aos Códigos de Deontologia e Ética; públicos, como os Juramentos; ou de consciência, que são as Orações. O modelo destes últimos é a Oração de Maimônides, apresentada neste artigo.
\end{abstract}

Descritores: Ética Médica. Bioética.

\section{INTRODUÇÃO}

A se formar, o verdadeiro médico assume, com sua comunidade e seus pacientes, compromissos que incluem e beneficência, a não-maleficência, a justiça com equidade e o respeito a autonomia, que são os quatro princípios básicos da Bioética Principialista'. Esses compromissos tem sido repetidos, com maiores ou menores modificações, ao longo dos tempos, e são de três tipos: os Juramentos, as Orações e os Códigos Ético-profissionais.

Os Juramentos são compromissos assumidos publicamente pelos médicos. É pena que hoje sejam, em muitas Faculdades de Medicina, feitos em ambiente totalmente impróprio, ao som de cornetas e "torcidas", como as de futebol, e em ambiente carnavalesco. Os Juramentos são lidos e repetidos mecanicamente, sem que se preste muita atenção nos compromissos que estão sendo assumidos. Temos proposto, sem sucesso, que a sagrada cerimônia do Juramento de Hipócrates seja feito em momento de reflexão, separado das comemorações festivas.

Pouco tem sido falado a respeito das Orações, que são compromissos tão importantes quanto os Juramentos, pois são assumidos interiormente, com a própria consciência, na forma de Oração.

\section{Maimônides}

Reflexões sobre a Oração do Médico de

Mose Ben Maimon (Maimônides) viveu de 1.135 a 1.204. Médico, poeta e humanista trabalhou durante o período áureo da chamada Medicina Arabesca, que acom- panhou o crescimento do domínio islâmico, inicialmente pela península arábica, conquistando em seguida a península ibérica, através do Estreito de Gilbratar. No auge de seu crescimento incluiu grandes partes da Europa, da Ásia e do norte da África. Esse mundo islâmico era dividido em dois califados, o oriental, com capital em Bagdá, e o ocidental, com capital em Córdoba. Na História da Medicina o grande mérito desse período foi ocupar o lugar da Europa, que passava por um período de trevas, com a destruição e queima de bibliotecas e livros e perseguições às lideranças culturais, incluindo médicos. Paralela e sincronicamente ao período de obscurantismo europeu se desenvolvia o mundo islâmico, importando os avanços da medicina ocidental, aos quais acrescentou muito em diferentes áreas, incluindo a Cirurgia, a Oftalmologia, a Farmácia, as instituições hospitalares e a preocupação com os aspectos éticos da Medicina. Historicamente chama atenção a tolerância cultural e respeito com os chamados " povos do Livro". O "Livro" era a Bíblia Sagrada em seu velho Testamento e os "povos do Livro" eram os cristãos e judeus. É somente dentro dessa atmosfera de respeito que se pode entender que Ben Maimon, judeu, pudesse ter as oportunidades e o prestígio que teve em Córdoba. Mais emblemático ainda é o fato de que, após ter problemas com o governo do Califado Ocidental, ele tenha sido convidado a se mudar para Marrocos, onde foi médico particular de Saladino, o chefe militar muçulmano. Era a Medicina, por meio de um de seus grandes nomes, sobrepujando diferenças culturais e religiosas. Nesse ambiente, Maimônides produziu a preciosidade que transcrevemos abaixo.

1. Diretor do Departamento de Defesa Profissional do CBC. Doutor em Cirurgia. Membro da Câmara Técnica de Bioética do Conselho Regional de Medicina do Estado de São Paulo. Coordenador do Departamento de Bioética e História da Medicina do Centro Médico de Ribeirão Preto. 


\section{ORAÇÃO DO MÉDICO (MAIMONIDES)}

- "O Deus, Tu formaste o corpo do homem com infinita bondade; Tu reuniste nele inumeráveis forças que trabalham incessantemente como tantos instrumentos, de modo a preservar em sua integridade esta linda casa que contém sua alma imortal, e estas forças agem com toda a ordem, concordância e harmonia imagináveis. Porém se a fraqueza ou paixão violenta perturba essa harmonia, estas forças agem uma contra as outras e o corpo retorna ao pó de onde veio. Tu enviaste ao homem Teus mensageiros, as doenças que anunciam a aproximação do perigo, e ordenas que ele se prepare para superá-las.

"A Eterna Providência designou-me para cuidar da vida e da saúde de Tuas criaturas. Que o amor à minha arte aja em mim o tempo todo, que nunca a avareza, a mesquinhez, nem a sede pela glória ou por uma grande reputação estejam em minha mente; pois, inimigos da verdade e da filantropia, eles poderiam facilmente enganar-me e fazer-me esquecer meu elevado objetivo de fazer o bem a teus filhos.

Concede-me força de coração e de mente, para que ambos possam estar prontos a servir os ricos e os pobres, os bons e os perversos, amigos e inimigos, e que eu jamais enxergue num paciente algo além de um irmão que sofre. Se médicos mais instruídos que eu desejarem me aconselhar, inspira-me com confiança e obediência para reconhecê-los, pois notável é o estudo da ciência. A ninguém é dado ver por si mesmo tudo aquilo que os outros veem.

- Que eu seja moderado em tudo, exceto no conhecimento desta ciência; quanto a isso, que eu seja insaciável; concede-me a força e a oportunidade de sempre corrigir o que já adquiri, sempre para ampliar seu domínio; pois o conhecimento é ilimitado e o espírito do homem também pode se ampliar infinitamente, todos os dias, para enriquecer-se com novas aquisições. Hoje ele pode descobrir seus erros de ontem, e amanhã pode obter nova luz sobre aquilo que pensa hoje sobre si mesmo.

Deus, Tu me designaste para cuidar da vida e da morte de Tua criatura; aqui estou, pronto para minha vocação."

(Moses Ben Maimon- 1.135-1.204))

A Oração de Maimônides é o modelo de compromisso pessoal do Médico

É fundamental repeti-la periodicamente. De cada Médico o que a sociedade espera é que tenha, ao longo de sua vida, o comportamento e as ações envolvidos nesta Oração, justificando plenamente o porque de alguém, que exerceu sua profissão na Idade Média, continuar vivo no coração dos verdadeiros Médicos².

\title{
A B S T R A C T
}

\begin{abstract}
Science / Art millennial, medicine involves, by its nature, a strong commitment to basic principles of bioethics that are summarized in the pursuit of health and welfare of people and communities in their broadest sense. Such commitments may be more formal, such as obedience to the Codes of Ethics and Ethics; public, such as oaths, or consciousness, which are the prayers. The latter model is the Prayer of Maimonides, presented in this article.
\end{abstract}

Key words: Medical Ethics. Bioethics.

\section{REFERÊNCIAS}

1. Beauchamp TL, Childress JF - The principles of biomedical ethics. $3^{\text {rd }}$ ed. New York: Oxford University Press; 1989.

2. Jorge-Filho I, Nunes MPT. Compromissos e deveres de conduta dos Médicos. In: Jorge-Filho I. Cirurgia geral: pré e pós-operatório, $2^{\text {a }}$ ed. São Paulo: Atheneu, 2010. No prelo.
Recebido em 12/04/2010

Aceito para publicação em 06/05/2010

Conflito de interesse: nenhum

Fonte de financiamento: nenhuma

Como citar esse artigo:

Jorge-Filho I. Os compromissos do médico: reflexões sobre a oração de

Maimônides. Rev Col Bras Cir. [periódico na internet] 2010; 37(4).

Disponível em URL: http://www.scielo.br/rcbc 